\title{
London and the Greater London Council: restructuring the Capital of Capital $^{1}$
}

\author{
Robin Murray
}

When I joined the $\mathrm{GLC}^{2}$ from the Institute of Development Studies two years ago, I was often asked what relevance I thought Third World experience would have for economic strategy in an advanced capitalist city.

Some comparisons immediately suggest themselves. London, with 400,000 unemployed, now has the greatest concentration of unemployment of any city in the advanced world. In the last decade it has lost more than half a million jobs. Severe poverty, particularly among the sweated trades in East London, exists within sight of the new offices of one of the richest square miles in the world. It is a contrast reminiscent of major Third World cities, as is the growing informal economy which has accompanied the rise of unemployment.

Yet one hesitates to push even the immediate comparisons too far. London is still one of the major metropolitan capitals of the world economy. The issues facing it are de-industrialisation rather than industrialisation. The drift of its population is away from the city rather than towards it. There is still a trade union tradition and welfare state, which however much under seige, is markedly different from the great majority of Third World countries today.

Contradictions have been much sharper in the Third World. As a result the economic debates have raised issues and argued strategies which are the very ones relevant to metropolitan economies caught as they are in the gathering recession. In this article I want to look at London and the question of an appropriate

\footnotetext{
1 This article is an edited version of a lecture given at the Development Planning Unit, University College, London on 13 February 1984. A full version of the text is available from the DPU.

2 The Greater London Council (GLC) is the metropolitan authority for London. In 1981 a left wing administration was elected which has pursued radical policies in the fields of transport, the arts, women's rights, anti-racism, and industry and employment. In part as a result of these policies, the GLC and other metropolitan authorities are now threatened with abolition by the British Government.
}

economic strategy in relation to two such perspectives i) the internationalisation of capital and ii) the role of the market and economic growth. I will then say something about the strategy being put into practice by the GLC.

\section{International London}

First, I am repeatedly struck by the insularity of analysis and policy in relation to London. At its narrowest, the analysis moves scarcely beyond the boundaries of London itself. London emerges from the wings with certain geographical and/or historical advantages, a centre of government and trade, and therefore of markets. Exogenous factors are introduced to explain the arrival or disappearance of this trade or that. There are no theorems about the growth of the London economy, because economic theorems cannot be generated from a geographical space whose existence as an economy (rather than a geographical mapping) has become increasingly problematic.

Nor is a national framework adequate to understand London's economy, either now or in any of the long cyclical downswings of the last 100 years. During the depression of the later 19th century, London's economy survived because of the empire. Its largescale industries - shipbuilding, engineering and silk weaving - had effectively collapsed by the 1870 s. The industries that survived - clothing, footwear and furniture - did so through matching the more advanced production methods in the provinces and abroad, by a resort to sweating. Those trades that were still tied to London by raw materials or markets moved out of Inner London, leaving an industrial vacuum behind.

In spite of losing out in the course of a period of major economic restructuring on the continent as well as in Britain, London's economy actually grew. It did so because London was still the administrative and commercial heart of the largest empire in the world. This was the age of the rebuilding of Whitehall, of the

IDS Bullesin, 1985, vol 16 no 1, Institute of Development Studies, Sussex 
rise of those great department stores like Liberties, the emporia of imperial produce, where the goods and money derived from the empire met on home soil. It was the period when the range and techniques of international banking and insurance were transformed, and London was the acknowledged international centre for both. London's expansion was not an export-led growth, but an imperial-led growth, based on finance, commerce and power rather than industry.

In the 1930 s the situation was quite different. London's economy was sustained during the world depression by industrial import substitution rather than free trade in commercial services. There were two pillars to this process. The first was the motor industry, protected behind tariffs with production serving the home market. The second was electricity. The reorganisation of the electricity industry between 1926 and 1933 led to an explosion of domestic consumption. In 1920 there had been $0.7 \mathrm{mn}$ consumers of electricity. By 1938 there were $8.9 \mathrm{mn}$. London led the way, both in consumption and in the new electrical engineering industries which grew up in response.

So London in the inter-war period was doubly fortunate. First tariffs and the breakdown in free trade forced international competitors to locate in the UK. Secondly, the fact that mass production of goods preceded an adequate national communications system for their distribution, meant that they were located in or near the largest market, namely London. While the rest of the country showed no growth at all over the key years of recession (1930-35) London's production grew by nearly 13 per cent. In the late 19 th century London grew because of the growth of free trade. In the 1930 s her economy grew because of its breakdown.

In the last 25 years London's position in the international economy has again changed. Following the trade liberalisation of 1958 , and particularly after British entry into the EEC in 1972, London has been drawn into a European division of labour. Increasingly we have seen the spread of international corporate economies, multinational firms like Kodak, Ford, Philips, and ITT, operating their own planned intrafirm international divisions of labour, and from the 1960 s making Europe an area for such integrated intra-firm specialisation.

In services, too, London has been gathered into an ever more complex international web. London became the centre of the eurodollar market from the late $1950 \mathrm{~s}$ and a key site in an increasingly internationalised capital market. Most of London's top consultancy and accounting firms are themselves international, many of them American owned, as are the top advertising agencies. London's major engineering consultancy and design firms rely on the export market, both to Europe and those areas of the Third World that have traditionally been within the European penumbra - Africa, the Middle East, and parts of Asia. London has also become a European junction for passengers, with a rapid growth in hotels to accommodate them - comfortable warehouses for the human entrepot trade.

The key point about the Europeanisation of capital is that London now finds itself competing not just with other parts of Britain but with other parts of Europe as a site for these functions. In telecommunications for example there has been an acute competitive battle over international traffic. For the time being British Telecom (BT) (and this means London) has been winning, by virtuc of cutting international charges and funding deficits from domestic charges. We can speak of the last 25 years as a period more of free transfers than of free trade. In the sphere of goods, more and more international movements are taking place within firms, not between them. In 1976 multinationals accounted for 70 per cent of British exports. Of the largest 31 exporters, intra-firm trade was nearly two fifths of total trade. Overall, the figure for $\mathrm{UK}$ trade was a third.

Even more important has been the movement of information and people - international transfers rather than trade, which has assumed a new significance in the knowledge and information economy of modern capitalism. Telecommunications and airports have replaced the electric grid and roads as the dominant infrastructure of the 1970s and $1980 \mathrm{~s}$.

Why should all this matter from the point of view of strategy? Principally because all analysis implies a strategy, just as each strategy has its own analysis. Urban and regional studies which have emphasised the relocation of industry between London and the rest of the country as the principle issue, thereby give strategic prominence to policies which might halt industrial drift. But the evidence of these studies makes it quite clear that it is not the redistribution of industry within Britain which is the major cause of job loss in London. The main causes should be sought in production, not in distribution, and in the consequences for industry and employment of the restructuring of London's economy in the context of Europeanisation. London's manufacturing industries have been subject to major changes in the production process linked in most cases to new electronic technology. The fact that London's manufacturing has seen a much steeper decline in employment ( 37 per cent) than in industrial output ( 14 per cent) during the $1970 \mathrm{~s}$, is an indication of the sharp rise in labour productivity that has led to the shedding of labour from London plants. 
Equally the fall in output of 14 per cent during a period that was still marked by industrial growth, reflects in part the shift of industrial production to the continent and beyond. Put in market terms, it reflects the declining competitiveness of British industry. For purposes of strategy it is to the issue of restructuring in a European context rather than competition with the declining regions in Britain that we should turn our attention.

Similarly with services and the new infrastructure. There is a major restructuring of the means of communication now taking place associated with the technological and geographical changes of the current downswing. On the one hand, the Port of London Authority supervised the run down of London's upper docks. On the other, the growth of Heathrow, and its attendant office, warehouse and hotcl development, has driven up prices in West London and, over the last four years, forced a wave of manufacturing closures. Its development, along with the changes in Britain's motorway network, has forced a major reorganisation of the West London economy.

If we wish to intervene in this all-pervading process of restructuring, we cannot limit ourselves to issues of industrial location within Britain alone. The debates about premises, wages rates, green and pleasant fields and regional grants seem miles away from the front line of the battle. The context of restructuring is the development of the transnational European economy. It is this which is redefining London's role as the capital of capital, and to which our strategies must therefore be addressed.

Equally important, the very process of Europeanisation changes the effectiveness of different instruments of policy. One example is banking. In the words of The Banker: 'The internationalisation of key financial markets ... is a major constraint on the Bank of England's role in supervising the regulation of the London Stock Exchange. If restrictions are too tight, large sections of the market will simply disappear elsewhere - something that has already happened to the business in South African gold shares', [November 1983, no 698, p 101]. Another example is in the field of industrial investment. Multinational companies Nissan is the most recent example - play off one EEC country and region against the others, with respect to grants, tax concessions, cheap finance, and so on. The result, in the UK as in Ireland, has been a major reduction in the net tax rates on multinational business (that is, tax net of grant and other subsidies). A study of 17 of the top 20 UK companies in 1982 showed that 14 of them paid no Corporation Tax at all, as the result of offsets, allowances, and declared losses.
In these cases, the multinationalisation of capital has introduced a new political economy of nation-states. They are brought into competition not through the exchange of goods and services on the international market (the traditional model of international trade), but through attempted attraction of multinational investment on the one hand, and multinational profit declaration on the other. The traditional instruments of international trade - changes in exchange rate, exchange controls, tariffs, monetary and now fiscal policy - have all been shown to be eroded by the force of the transnational corporate economy.

The 75 factories in London which - in October 1982 - still had more than 500 workers are all, with two exceptions, owned by multinationals. London's major offices, advertisers, accounting firms, engineering firms, financial institutions, insurance companies are again predominantly owned by multinationals. They dominate the commanding heights of the London economy. Yet their very multinationalisation restricts the effects of conventional public intervention. Local and national government is bound by its competitors in such an economy, as an enterprise is bound by the level of its competitors' prices.

It would be to lose a dimension to see London solely in its international context. It is - and has been for the last four hundred years - a capital of national capital. Yet that said, London's changing structure - its dynamic - can still be best understood in terms of its changing place in the international division of labour.

Development economists will recognise in this one of the themes in the analysis of Third World economies today. There has, of course, been strong debate between national approaches to Third World studies, and those which emphasise the international determination of the course of these economies. The precise relationship between national states and the international economy has still been far from adequately resolved - whether at the level of abstract theory (neo-classical, Ricardian or Marxist), or at the level of concrete analysis. But with smaller and less developed countries in particular, it has been difficult for anyone not to acknowledge the overarching dominance of international economic forces. This is the first contribution development studies can make to our understanding of London.

\section{London, the Market and Accumulation}

The second contribution is in the field of economic growth. The debate on growth theory is no more than the debate on development, running from the changing emphases on money capital, consumption, skilled labour, entrepreneurship and technology, to more general theories of capital accumulation. The 
debates on strategy have centred round these theories: how to increase savings, aid or trade, import substitution or export promotion, foreign investment versus the development of national industry, alternative channels of technology transfer, primitive socialist accumulation versus international capitalist accumulation and so on.

One line in the development debate has been reflected in urban analysis - that which advocates a more or less hard version of the free market strategy. According to this, development will take place as long as the conditions and mechanisms of capitalist circulation are working. In development theory, many obstacles have been identified over the years: the family farm, the backward bending supply curve of labour, the absence of local capital markets, fluctuating export markets, over-protected local economies, and many various state 'interferences'. Even the radical literature has commonly identified the causes of underdevelopment with imperfections in the circulation process - particularly the dependency school: unequal terms of trade because of imperial monopolies, multinational companies favouring capital intensive rather than labour intensive methods of production, internal pre-capitalist ruling class monopolies over savings, markets, firms, and labour. Behind them all was some version of the free market, non-skewed consumption patterns, and in progressive versions, more equal distributions of income.

The parallel for London is that London cannot 'buck the trend'. Manufacturing is effectively finished for London, and should not be saved. Instead the task for the GLC should be to prepare the necessary infrastructure for the new service industries, attract in new projects (such as the Olympic Games or a new airport in Docklands) and advertise London's qualities to overcome any imperfections in information. The new orthodoxy in planning theory is to dismantle public controls in land use planning, and to take the state out of the urban economy.

More moderate policies concentrate on the state making good where the market has for some reason failed. The supply of premises for small businesses is particularly popular at the moment. So is the encouragement of small firms, of free market competition and innovation. In these cases state intervention is justified, as it is in the provision of advice and soft loans for such businesses. Other instances are the provision of training, the recla mation of derelict land, or the building of roads in order to bring particular premises and areas back into the market.

In these approaches the question of accumulation goes by default. If markets are working, if taxation and state regulation does not disadvantage an area, or curb incentives, then saving and re-investment will look after itself.

In the Third World, this approach has been vigorously challenged. It was so clearly in the interests of the dominant metropolitan powers to have free markets into and within Third World countries, that a critical literature developed. In orthodox theory the exceptions to the market rule defined themselves in terms of the market: the infant industry argument for protection and even the infant economy argument. Both implied that the interruption of free trade would be temporary. Public intervention in the free market was also justified on the grounds that there existed external economies and diseconomies, but the concept and its application again confirmed the overall robustness of market theory. They might equally be analysed as 'beyond the market economies', or economies internal to non market models of allocating labour. What was rapidly rediscovered was that the doctrine of free trade, like free markets, was in Joan Robinson's words 'the mercantilism of the strong'. Structural inequalities meant that free market relations would as surely favour the strong, as would a hundred-yard race favour the able bodied over the lame. Marxist theory offered the most substantial account of how such structural inequality (spatial, as well as social, corporate, as well as international) was produced and reproduced through the mechanism of capitalist circulation.

If the market could not be relied on, then alternative theorems and guidelines were required for development. Preobrezensky advanced a strategy based on raising labour productivity in agriculture, switching agricultural surplus product to manufacturing, and appropriating Western technology under the strictest monopsonistic terms to improve labour productivity more generally. He and other members of the Left Opposition in the 1920 s did not ignore the world market, indeed as one of them said, the price catalogues of the capitalist world market provide the measure against which the advance of socialist accumulation can be judged. But the allocation of labour within the Soviet economy, its strategic direction, the apportioning of investment goods none of these relied on comparisons of individual market prices.

I cite the case of the Soviet Union in the 1920s because it produced some of the most articulate and theoretically aware statements of economic development strategy which works in but against the market. Other import substitution strategies have diverged from market prescriptions but rarely with so coherent an alternative theoretical system. The tendency has always been towards individual project-based 
approaches rather than more macro strategies. Cost benefit analysis as used in many parts of the Third World has been the vehicle for this. At times the cost benefit argument seems to imply that all macro strategic policy can be expressed in accounting values. But it is not clear that the translation of general strategy into particular projects needs such quantification. Although modified, market prices are again the loadstone for project assessment. Once this project oriented approach is established, it has been but a short step to the introduction of world market prices via Little-Mirlees Manuals or the methodologies of the World Bank.

Given the strength of the debate in the Third World, it is striking how powerful and relatively unchallenged the principle of the market is in the London economy. I am not merely thinking of conventional local authority policies. There is also the profound ideological power of the concept of 'viability' and its poor cousin, 'subsidy'

Some of the objections to the use of the market as the basic criterion for restructuring the London economy remain within the static approach of market theory itself. I will list these briefly:

i) external economies which cannot be realised by individual enterprises because they cannot appropriate result of their investments; for example industrial training;

ii) inequalities of income (and/or mobility) so that changes which benefit one section of consumers are at the expense of others; for example supermarkets requiring private transport displacing neighbourhood shops;

iii) mass production which lowers unit cost but reduces choice;

iv) the presence of monopolies who drive out competition through price wars; a notable example is in London's bread industry;

v) locational decisions in which the social costs and benefits are not adequately reflected in market costs; this would apply to most cases of a shift of investment from London to green field sites.

In each of these cases there is a clear argument for public intervention, to ensure that restructuring takes place in a way which reflects wider social interests than those embodied in market prices.

But the arguments are still couched in terms of modifications of the market. Put another way, they represent micro interventions in and against the market. The macro strategic questions remain.

There are four more general objections to the market as an instrument of restructuring.

\section{i) Investment and the market}

The restructuring that is required is commonly on such a large scale, and is undertaken over such a long period, that the market is an inadequate guide to choice.

Major multinational companies have to determine their strategy with respect to systems and products that they believe will eventually become competitive but whose profitability they cannot possibly measure for many years to come. The Japanese are most noted for this point. They do not constantly apply Discounted Cash Flows (DCFs) and criteria of short term profitability. Their planning and financial systems are geared to the long, internationally strategic view, in a manner not unreminiscent of the Soviet economic strategies of the 1920s.

\section{ii) Crisis and the market}

In spite of its increasing inadequacy for many project decisions, the market remains the major instrument of economic restructuring. But the way in which such restructuring takes place at the macro level through economic crisis is so brutal, wasteful and actually dangerous, that it is astonishing that its uninhibited use is still so generally accepted. The pattern of crisis has been remarkably consistent. After 25 years or so of economic expansion, there has followed 25 years of downswing. During this period profit rates decline, competition sharpens, credit is extended, as is the new technology which is to dominate any future upswing. In the 1930s it was automobiles and electrical goods. From the mid 1960s it has been electronics, and oil based products. In all previous cases the depths of the depression have seen: a) a major financial crash and writing off of capital values; b) a sustained attack on wage levels and the control of labour within the production process; c) the increase of productivity through rationalisation, the introduction of new work methods and technology, and the speed up in the circulation time of production. It has also almost always been accompanied by massive unemployment and war. In other words major restructuring has always taken place at the expense of labour.

The period of monetarist policy since mid 1979, can be seen as an attempt to hasten this process. The exchange rate was intentionally driven up in order to squeeze profitability, discipline labour and drive out of business the less efficient firms. The result has been a massive rise in industrial closures and unemployment in London and elsewhere.

Nor has it been necessarily the least efficient who have been driven out, leaving the most efficient from which the new shoots of growth will spring. Take London's furniture industry as a case in point. The four largest 
firms are now ont of bissiness. Each needed long runs to break even, and could not cope when the recession hit. The less capitalised firms were more flexible and some have survived.

Further, power has been increasingly moving to the large retailers. They have been involved in restructuring retailing, and have been as pleased to import from abroad as to restructure the furniture producers at home. The resilt has been that for UK and London industry at least. the industrial base on which any renewed growth could take place has all but been destroyed. The pool of highly skilled workers in East London and on up the Lea Valley has been dissipated. The firms who remain have been nnable to match the strategies of continental manufacturers towards custom fitted furniture and large-scale precision panel cutting, or the design led cooperative associations in Italy. The destruction of London's furniture industry is paralleled in many branches of engineering.

\section{iii) Employment and the market}

There is no mechanism in the market economy to ensure that the destruction of some jobs will be matched by the creation of others. Rather the history of capitalist development has been one of creating a surplus population. This is how I read the phenomenon of unemployment in the Third World. On the one hand advanced count ry technology drove a rapier through artisanal forms of economy - in the countryside and in the small-scale crafts of the towns. Plastic, soft drinks, the tractor - these were some of the typical destroyers of traditional employment. Much of the resultant profit however was then repatriated to met ropolitan count ries for accumulation there. Advanced country accumulation and full employment was maintained, drawing in immigrant workers when the metropolitan labour supply was exhausted, at the expense of accumulation and employment in the Third World. In the current period, this mechanism has no longer been sustained. From the early 1970s the decline in levels of profitability led to money capital being exported back to the newly industrialising conntries (NICs) and to the socialist world. Accimmulation in the advanced conntries slowed down. New technology further reduced the demand for labour. Unemployment rates have risen dramatically through the advanced capitalist countries. Even with an economic upturn, there is no longer any guarantee of full employment, particularly in less competitive economies such as the UK. Ihis is why it is in no way enongh to accept the redefinition of London's place in the European division of labour, since it provides no promise of full employment.

\section{iv) Labour and the market}

The rule of the market always tends to bear down on the wages and conditions of labour. Cheaper labour will lead to lower prices and an undercutting of other labour. This is the key to understanding much of monetarist strategy, first against the private sector, and then against the state. The latter has now come to the forefront of the government's economic strategy in London as in the rest of the country. In local government at least this has singularly failed to work. Capital investment and the purchase of goods and equipment have been cult first, along with part-time workers.

The main body of unionised labour has remained remarkably strong. In addition the government has attcmpted to liberalise and privatise in order to weaken labour with in the state economy. The relevant point for our discussion is that money and the market have been used as instruments for the discipline of labour.

London's economy, therefore, must be seen not only in terms of its reorientation towards Europe, but in the context of a process of economic accumulation subject to quite definite laws. I have suggested that the market is an inadequate concept to understand this process of accumulation, even though the laws of this accumulation bear down on individual enterprises through the medium of the market and the principle of profitability. The market is not an adequate guide for strategy. It has currently plunged London into its deepest recession of the century. As a mechanism for identifying and rewarding the most productive, it has commonly closed down the potentially most efficient, and consigned to the sidelines with zero productivity 400,000 London workers, $32 \mathrm{mn}$ square feet of indistrial and commercial buildings, and many machines. So deep has the destruction been, that London may already have lost many branches of manufactıring permanently, regardless of an upturn. Over all this broods the threat of a major international financial collapse which would devalue capital as a precondition for a return to profitability. In these circumstances, the use of market-determined profitability as a guideline is profoundly mistaken. It is like a compass which is pointing the wrong way. So far from economic strategy being geared to freeing the market or perfecting it, it should be directed primarily against the market, even while operating within it.

\section{Economic Strategy and the GLC}

The GLC's current economic strategy starts from the problem rather than its powers. I have outlined the problem as I see it in the earlier sections. I shall now discuss the strategy we see as necessary in this context. The central question is that of indistrial rest ructuring. We are quite clear that there is no institution adequately dealing with the issue in Britain, let alone 
in London. In the USA large-scale managerial capital has been organising industrial restructuring directly, as J. P. Morgan did in the 1930s, though on this occasion without the support of a New Deal interventionist government. In Germany the banks still perform the major role in restructuring, controlling much of German industry, and insisting on a clear 'hands-on' role. In Japan the task is being performed by MITl, effectively a Ministry of Industrial Planning, staffed by 2,500 professionals who co-ordinate industrial capitalists and the financial institutions in continual programmes of reorganising declining industries and growing ones. In Britain, since the days of the Industrial Reorganisation Corporation (IRC), and to a lesser extent the National Enterprise Board (NEB), there is almost nothing. The Ministry of lndustry has sponsored a number of schemes organised by management consultancy firms and merchant banks to restructure narrow branches of the engineering industry, but by and large the stock market remains the major instrument for restructuring, along with the large enterprises.

The GLC's Greater London Enterprise Board (GLEB) aims to be interventionist in these terms. It has built up a team which includes management consultants, accountants, trade unionists, technologists and property specialists, which is capable of intervening to prevent the closure of London's potentially profitable manufacturing firms. It now owns or partly owns 35 companies including factories making furniture, clothing, car components, computers, robots, shoes and electronic components. In all 200 enterprises have been assisted, saving or creating 2,000 jobs. This has been the first stage.

But GLEB's aim is to go beyond single interventions of this kind. It has built up a strategy division, together with the Economic Policy Group in the GLC, which is devising strategies for those industries over which the GLC and GLEB can hope to have some influence: furniture, clothing, printing, instrument engineering, catering and the cultural industries. The aim in each case is to consider the position of London's industry within an international context, and its prospects of market survival if it was reorganised, with modern equipment, consolidated design and marketing. The emphasis is on productivity, careful fashioning of the product, and, where possible, reconstruction after a devaluation of capital (usually through a receivership).

Our second major point is that the restructuring which does take place need not occur in any one way, or in any one place. Our concern is to ensure that it is moulded to the needs of ordinary Londoners, both as workers and consumers. To begin with, GLEB only assists firms which allow access to trade unions, and which agree to sign an Enterprise Agreement. This is an agreement involving the enterprise, the trade unions and GLEB, and governing the overall direction of the business, conditions for the workforce, training provision, and so on. It also may involve representatives from the workforce sitting on the management board.

Already in the firms funded or taken over, jobs have been preserved or created in ways which maintain the organised strength and involvement of the workforce. But in some sectors we can already see the process of 'restructuring for labour' going further. In London Transport the GLC resisted attempts to move to One Person Operated trains and buses, on the grounds that guards and conductors provide a service, and that it made no economic sense to cut such productive labour at a time of high unemployment. Instead it aimed to increase prductivity through expanding the service, redesigning ticketing systems, and in tegrating different parts of the transport network.

Similarly in the field of new technology. There is no one new technology. Work with which the GLC and GLEB have been closely engaged at the University of Manchester Institute of Science and Technology, has shown how numerically controlled lathes and automatic factory systems do not need to involve the deskilling of formerly highly skilled workers. They can be designed to build on that skill, and the lathes which are in operation have shown themselves more efficient than a lathe which depends on a white collar programmer to come down and put it right, while the semi-skilled operator looks on. Similarly, the technology networks GLEB has been developing as an alternative to Science Parks, have been applying the skills and capacities of universities and polytechnics to issues such as energy conservation, and new technology for health and the disabled.

We can put the general point in this way. The restructuring of industries and processes can take many forms. Private capital operating within the discipline of the market will tend to choose certain solutions, usually at the expense of labour. GLEB and the GLC believe that it is more rational and consistent with the general goals of a socialist economy, to develop alternative solutions, building on the ideas of the workforce themiselves.

GLEB has found that an institution of its size and resources ( $£ 30 \mathrm{mn}$ in the current financial year) can have most effect on medium sized, often family firms, ill managed, but with a skilled workforce and commonly a quality product. The GLC for its part has directed its activities towards the restructuring taking place in state industries - British Telecom, the Central Electricity Generating Board, the Port of London Authority, the National Health Service, as 
well as London Transport. The other major economic institutions are the multinationals. Against them the GLC may be seen to have less power. The strategy we have adopted is to set up an early warning system, linked into the Trade Union movement, to identify potential closures and redundancies in the larger factories. The GLC then supports the unions within the plant. Sometimes it is a question of bargaining with the central management about closure. In other cases it has been supporting the development of an international combine of trade unionists in the same company to bargain with the international management about future investment plans and their location.

In each sector an adequate alternative strategy cannot be developed by council officials alone, however wellintentioned they are. It has to involve the workforce, sympathetic managers, and wherever possible the consumers as well. In London some 250,000 people are paid to think, design, invent, account, guide and co-ordinate public and private enterprise and public services. They work approximately seven million hours thinking a week. Most of this thinking is locked into the directions dictated by the market. For a substantial rather than formal development of economic democracy, we feel strongly that there must be time other than in the evenings for ordinary people to think about and plan their industries. They should be able to call on the services of thinkworkers thinking on their lines rather than those dictated by profitability. To this end we have funded nearly 120 people whose task it is to be a resource of this kind.

The Council has some further powers to contribute. On the side of finance, we have set up a London-wide investment fund, sourced from London public pension funds. We have also begun to use our shareholder power with respect to major companies, and are involved in a scheme, already well established in the United States, to link different local authorities together to increase shareholder power.

The council is a major purchaser. When marketing and brand names are substantial barriers to entry, Council purchasing is a potential lever on large suppliers. In New York, school meals purchasing has been used to change the quality and ingredients of supplies, with a significant impact on children's diets. We are implementing a similar scheme here. We have also set up a Contract Compliance Unit which is an investigatory body to ensure that suppliers follow the GLC codes of practice on equal opportunities for women and for black people.

Some of the major ways of controlling the market economy lie outside our capacity. We are not a monetary authority, nor can we operate tariffs and exchange controls. We do not control an army - though we have pressed for more accountable and local control of the police. The absence of these powers to intervene in circulation has helped us to concentrate on issues of production and productivity. But undoubtedly the broader powers would be required for any macro attack on the current levels of unemployment and depression.

Having said that, however, Keynesian reflation by itself will not restore full employment. It has to accompany the kind of detailed industrial policy I have outlined. It is a policy which has to adddress the issues of productivity, technological change, and strategic restructuring within an international context.

It has to do this because the key condition for capitalist accumulation is profitability, and the conditions of profitability are primarily determined in production. Keynes - mistakenly in my view identified the conditions for macro profitability in consumption, and Keynesian policy is above all directed at the spheres of consumption and distribution, to alter the aggregate levels of demand. Macroeconomic management of the main variables of circulation have pride of place in Keynesian strategy: levels of taxation, interest, and exchange rates. Industrial policy is consigned to a subordinate role.

At the GLC we believe this relation should be inverted. We see industrial policy as being primary, conducted not through the general manipulation of markets, but by particular interventions in production, enterprise by enterprise, and branch by branch. It is a strategy of detail, concerned with all the awkwardness of material production, in contrast to the financiers's disdain of detail and preference for the abstract world of money and the market. General economic management should be subordinate to industrial policy.

As long as the market and profitability remain the main economic mechanisms there will be an inherent tension with these material goals. In intervening in the market economy, what we aim to do is to strengthen the socially useful forces, however bound they may finally be by the conditions of profitability. This is why we speak of operating in and against the market.

The government is opposed to the GLC's strategies for transport, employment, redistribution, energy, the arts, housing, construction, the democratic accountability of the police, and effective action against discrimination. In all these the GLC has been trying to construct alternatives to those advanced by the government. The abolition proposals and the campaign against them have put urban strategy at the centre of British politics. 
Third World countries have often experienced the pincer movement between the economic discipline of the market on the one hand, and the political discipline of an authoritarian state on the other. There are parallels now emerging in London as in Britain as a whole. London, like the Third World, now faces a conflict of strategies whose outcome will shape the way in which it develops, and for whom, for the rest of the century. 